\title{
2012-13 APSA Congressional Fellowship Program Office Assignments
}

$\mathrm{F}$ ounded in 1953, the APSA Congressional Fellowship Program is the nation's oldest and most prestigious congressional fellowship. More than fifty years later, the program remains devoted to its original objective of expanding knowledge and awareness of Congress. For nine months, select political scientists, journalists, doctors, federal executives and international scholars gain "hands on" understanding of the legislative process by serving on congressional staffs. Through this unique opportunity, the Association enhances public understanding of policy-making and improves the quality of scholarship, teaching and reporting on American national politics. For more information about the program visit https://www.apsanet.org/cfp. The assignments for 2012-13 are listed below.

\section{US HOUSE OF REPRESENTATIVES}

Joshua Carstens Huder

Rep. Keith Ellison (D-MN)

Jason E. Thomas

Rep. Dan Benishek (R-MI)

Scott Gutierrez

Rep. Dan Lipinski (D-IL)

\section{Arlene Bierman}

Rep. Jim McDermott (D-WA) and

Department of Health \& Human Services,

Office of the Assistant Secretary for

Health

Maes Suwantra

Rep. Tammy Duckworth (D-IL)

Kevin Wozniak

Rep. Bobby Scott (D-VA)

Amir Fairdosi

Rep. Matt Cartwright (D-PA)

Brooke Hollister

Rep. Nancy Pelosi (D-CA)

Nicole Fletcher

Rep. Charles Rangel (D-NY)

US SENATE

Christopher A. Landberg

Sen. Robert Menendez (D-NJ)

Bruce Edgren

Sen. John D. Rockefeller, IV (D-WV)

Maureen Henry

Sen. Mark Warner (D-VA)

Andrew Gettinger

Sen. Orrin Hatch (R-UT)

Ian Ostrander

Sen. John McCaskill (D-MO)

\section{COMMITTEES}

Barbara Damron

Senate HELP Committee, Minority-

Lamar Alexander (R-TN)

Peter E. Sokolove

Senate Finance Committee, Majority

Erik Abjornson

Senate Finance Committee -

Sen. Orrin Hatch (R-UT)

Melanie M. Marlowe

House Committee on Oversight

and Government Reform

Tyson King-Meadows

House Committee on the Judiciary, Minority

Rebekah Grindlay

House Committee on Energy and

Commerce, Majority

Harry J. Heiman

House Energy and Commerce

Committee, Minority

\section{Stephen Ferrara}

House Energy and Commerce

Committee, Majority

Karen B. Domino

House Ways/Means, Minority

Kenneth Brummel-Smith

Special Committee on Aging

\section{LEGISLATIVE BRANCH}

Anthony J. Madonna

Congressional Research Service, Government \& Finance Division, Legislative \& Budget Section

Hassan Tetteh

Congressional Budget Office

\section{EXECUTIVE BRANCH}

Emily Nicklett

Centers for Disease Control

Christine Bishop

Department of Health \& Human

Services, Offices of the Assistant

Secretary for Planning \& Evaluation,

Disability, Aging \& Long-term Care

Policy

Susan Lynch

Department of Health and Human

Services, Center for Medicare and

Medicaid Services, Standards \& Quality

\section{Joan Penrod}

Department of Health and Human

Services, Center for Medicare and

Medicaid Service

Joan Davitt

National Committee to Preserve

Social Security \& Medicare

Christine Bishop

Assistant Secretary for Planning and

Evaluation

Rajean Moone

Administration on Aging

Minnesota Board of Aging

The Congressional Fellowship is supported by the generosity of MCI; American Australian Association; Atlantic Philanthropies Health and Aging Policy Fellows Program; The Asia Foundation; Robert Wood Johnson Foundation Health Policy Fellows; Central Intelligence Agency, Leadership Development Program; Department of State Career Development and Training; and the contributions of former fellows. 